\title{
Exploring the relationships between retail brands and consumer store loyalty
}

\author{
Somayeh Malek Mohammadi*
}

Department of Management and Accounting, South Branch, Islamic Azad University, Tehran, Iran

\begin{tabular}{|c|c|}
\hline C H R O N I C L E & A B S T R A C T \\
\hline $\begin{array}{l}\text { Article history: } \\
\text { Received March 18, } 2015 \\
\text { Accepted April } 162015 \\
\text { Available online } \\
\text { May } 142015 \\
\text { Keywords: } \\
\text { Retail brand } \\
\text { Organizational competitiveness } \\
\text { Retail location }\end{array}$ & $\begin{array}{l}\text { This paper presents an empirical investigation to study the effects of retail brand on } \\
\text { organizational competitiveness. The study has accomplished among } 247 \text { randomly selected } \\
\text { retail stores located in city of Tehran, Iran. We have designed a questionnaire in Likert scale } \\
\text { and distributed the questionnaires among some managers of retail stores. Bartlett KMO and } \\
\text { Cronbach alpha have been calculated as } 0.7 \text { and } 0.863 \text {, respectively, which are within the } \\
\text { desirable levels. Using principal component analysis, the study has detected five factors } \\
\text { influencing on organizational competitiveness including effective brand, distribution } \\
\text { management, customer strategy, retail location and competitive tools. The highest value } \\
\text { belongs to retail location ( } \beta=1.196) \text { followed by distribution management }(\beta=0.825) \text {, } \\
\text { effective brand }(\beta=0.47) \text { and competitive tools }(\beta=0.470) \text {. }\end{array}$ \\
\hline
\end{tabular}

(C) 2015 Growing Science Ltd. All rights reserved.

\section{Introduction}

Retail stores are important part of Iranian domestic product. In fact, there is one retail store per 38 Iranian residences, which is remarkable rate in the world. This is because of globalization, rapid and sustainable growth of the economy, changes in consumer preferences and, in particular, the increase in combination of consumer goods and disposable income (Borghini et al., 2009). The profitability of retail activity in Iran's economy due to the small volume of investment required is not comparable with any other activities. Retail marketing includes all activities related to the sales of goods or services directly to the final consumer. In current competitive world, different products use various procedures to reach market success in global market and to remain on the market, firms need to pay especial attention to intangible assets. There are different intangible assets in each organization such as human resources, good will, etc. (Pan \& Zinkhan, 2006). Brand and its place on consumers' mind plays essential role on the success of organizations. Most part of consumers' perspective about any particular brand depends on the product purchases on the market. The main reason for the slow rate of development of the retail industry in the world is associated with risk of investment that many investors consider for participating in the establishment of chain stores. In fact, since the return on capital and earnings of these firms are still not reliable many investors prefer other ways to invest. In addition, the 
high cost of property, poor producers in supplying the required goods and lack of familiarity of retail stores' managements on advanced methods are the main reasons for the failure of retail stores. The primary objective of many retail stores in building a good brand is associated with customer retention through customer loyalty. In fact, customer relationship marketing emphasizes that loyal customers are core business assets and the nature of communication and business management describes the concept of customer loyalty. Loyal customers are not very sensitive to prices, the cost for absorbing new customers is reduced, which increases the profitability of organizations. Binninger (2008) reported that the increase in retail brand (RB) satisfaction and loyalty could influence on store loyalty, and that behavior toward RB products maintains a moderating impact on the relationships between $\mathrm{RB}$ satisfaction and loyalty. They also indicated that this moderating influence was bigger for an identifiable retail brand than for an unidentifiable retail brand.

Gee et al. (2008) gave some insight on the salient issues surrounding customer loyalty and customer relationship management (CRM) into a single coherent discussion and emphasized on the need for businesses to retain customers. Guenzi et al. (2009) developed and examined a model of customer trust in a retail service setting. Three levels of the customer-to-store relationship were simultaneously considered including customer to sales associates, customer to store branded products, and customer to the store itself. They reported that trust in the salesperson and trust in store branded products had positive impacts on overall store trust. Granot et al. (2010) developed theory-building exploratory study to investigate how female shoppers make meaning in a branded-retail store shopping experience. The study extended previous studies on retail consumers' decision-making and the retail shopping experience based on hermeneutic phenomenology. They built in-depth interviews with respondents, who were self-identified customers of a leading intimate apparel retailer. They reported that consumers' retail shopping decision-making could incorporate a complex set of interactive components, which were brand-driven and simultaneously influence and were influenced by the interaction of in-store shopping and retail setting.

Keeling et al. (2013) examined how customers perceive a range of technologically mediated and faceto-face retail relationships compared with core social relationships. Kim et al. (2007) provided some insight into the nature of the membership fee based on a model of price competition between a warehouse club and a supermarket. They explained that the warehouse club's membership fee was an optimal competitive reaction to the supermarket's promotional activity. Lymperopoulos et al. (2010) analyzed the role of "trust" and "confidence/pessimism" in influencing consumer attitudes and buying intentions with respect to retail brands and products. They reported that the consumers' degree of confidence/pessimism regarding their general economic situation and their trust in retail brands were affecting the perceived benefits and indirectly their attitudes. According to Pan et al. (2006) "the retail patronage idea includes such key concepts as store choice and frequency of visit”. Pan et al. (2006) synthesized previous studies through a formal, critical review of retailing literature. The meta-analysis implied that different predictors such as service, product selection, quality were strongly associated with shoppers' retail choice, whereas others such as store attitude, store image were important antecedents of shopping frequency.

\section{The proposed study}

This paper presents an empirical investigation to study the effects of retail brand on organizational competitiveness. The study has accomplished among 247 randomly selected retail stores located in city of Tehran, Iran. The study designs a questionnaire in Likert scale and distributes it among some managers of retail stores. Bartlett KMO and Cronbach alpha have been calculated as 0.7 and 0.863 , respectively, which are within the desirable levels. Table 1 demonstrates basic statistics on data gathered from the managers who participated in our survey. As we can observe from the results, all statistics are within desirable values and we may therefore, use principal component analysis. 
Table 1

The summary of some basic statistics

\begin{tabular}{|c|c|c|c|c|c|c|c|c|}
\hline & & \multirow[b]{2}{*}{$\mathrm{N}$} & \multirow[b]{2}{*}{$\min$} & \multirow[b]{2}{*}{$\max$} & \multicolumn{2}{|c|}{ Skewness } & \multicolumn{2}{|c|}{ Kurtosis } \\
\hline & & & & & Statistic & $\begin{array}{l}\text { Std. } \\
\text { Error }\end{array}$ & Statistic & $\begin{array}{l}\text { Std. } \\
\text { Error }\end{array}$ \\
\hline q1 & Suppliers of raw materials & 247 & 3 & 5 & -0.363 & 0.155 & -1.17 & 0.309 \\
\hline q2 & Strategic integration & 247 & 3 & 5 & -0.921 & 0.155 & -0.141 & 0.309 \\
\hline q3 & Internet sales & 247 & 1 & 5 & -0.283 & 0.155 & -0.116 & 0.309 \\
\hline q4 & Internet Retail & 247 & 1 & 5 & -0.372 & 0.155 & 0.046 & 0.309 \\
\hline q5 & Marketing channels & 247 & 2 & 5 & -0.591 & 0.155 & 0.385 & 0.309 \\
\hline q6 & Label information & 247 & 1 & 5 & -0.611 & 0.155 & 0.197 & 0.309 \\
\hline q7 & Quality products & 247 & 1 & 5 & -0.194 & 0.155 & -0.334 & 0.309 \\
\hline q8 & Competitive retail & 247 & 1 & 5 & -0.517 & 0.155 & 0.25 & 0.309 \\
\hline q9 & Power Retail & 247 & 1 & 5 & -0.999 & 0.155 & 1.461 & 0.309 \\
\hline q10 & Female consumers & 247 & 2 & 5 & -0.518 & 0.155 & -0.51 & 0.309 \\
\hline q11 & NPD & 247 & 1 & 5 & -0.104 & 0.155 & -0.757 & 0.309 \\
\hline q12 & Cash Discounts & 247 & 1 & 5 & 0.123 & 0.155 & -0.289 & 0.309 \\
\hline q13 & To compare prices & 247 & 1 & 5 & 0.152 & 0.155 & -0.502 & 0.309 \\
\hline q14 & Sellers behavior & 247 & 1 & 5 & -0.373 & 0.155 & -0.624 & 0.309 \\
\hline q15 & Customer service & 247 & 2 & 5 & -0.25 & 0.155 & -0.669 & 0.309 \\
\hline q16 & Shopping Experience & 247 & 1 & 5 & -0.806 & 0.155 & 1.503 & 0.309 \\
\hline q17 & Store household needs & 247 & 2 & 5 & -0.685 & 0.155 & 0.283 & 0.309 \\
\hline q18 & Market share & 247 & 2 & 5 & -0.23 & 0.155 & -0.434 & 0.309 \\
\hline q19 & Brand equity & 247 & 1 & 5 & -0.28 & 0.155 & -0.042 & 0.309 \\
\hline q20 & Brand management & 247 & 1 & 5 & -0.209 & 0.155 & -0.316 & 0.309 \\
\hline q21 & Credit Retail Brand & 247 & 1 & 5 & -0.147 & 0.155 & -0.416 & 0.309 \\
\hline q22 & Distribution channels & 247 & 1 & 5 & -1.033 & 0.155 & 0.977 & 0.309 \\
\hline q23 & The competitive structure of the market & 247 & 1 & 5 & -0.533 & 0.155 & -0.139 & 0.309 \\
\hline q24 & Loyalty Store & 247 & 1 & 5 & -0.331 & 0.155 & 0.126 & 0.309 \\
\hline q25 & Pricing strategy & 247 & 1 & 5 & -0.276 & 0.155 & -0.383 & 0.309 \\
\hline q26 & Advertising strategies & 247 & 1 & 5 & -0.346 & 0.155 & 0.095 & 0.309 \\
\hline q27 & Segmentation of the market & 247 & 1 & 5 & -0.892 & 0.155 & 1.063 & 0.309 \\
\hline q28 & Supply Chain Management & 247 & 1 & 5 & -0.701 & 0.155 & 0.837 & 0.309 \\
\hline q29 & Customer loyalty to the brand & 247 & 1 & 5 & -0.252 & 0.155 & -0.57 & 0.309 \\
\hline q30 & Music in store & 247 & 2 & 5 & -0.394 & 0.155 & -0.843 & 0.309 \\
\hline q31 & Bargaining power of customers & 247 & 1 & 5 & -0.163 & 0.155 & -0.444 & 0.309 \\
\hline q32 & Demand forecast & 247 & 2 & 5 & -0.384 & 0.155 & -0.98 & 0.309 \\
\hline q33 & Access to the shops & 247 & 1 & 5 & -1.091 & 0.155 & 1.16 & 0.309 \\
\hline q34 & Incentive policies & 247 & 1 & 5 & -0.377 & 0.155 & -0.25 & 0.309 \\
\hline q35 & Non-cash discounts & 247 & 1 & 5 & -0.429 & 0.155 & -0.38 & 0.309 \\
\hline q36 & Fair price & 247 & 2 & 5 & -0.154 & 0.155 & -0.948 & 0.309 \\
\hline
\end{tabular}

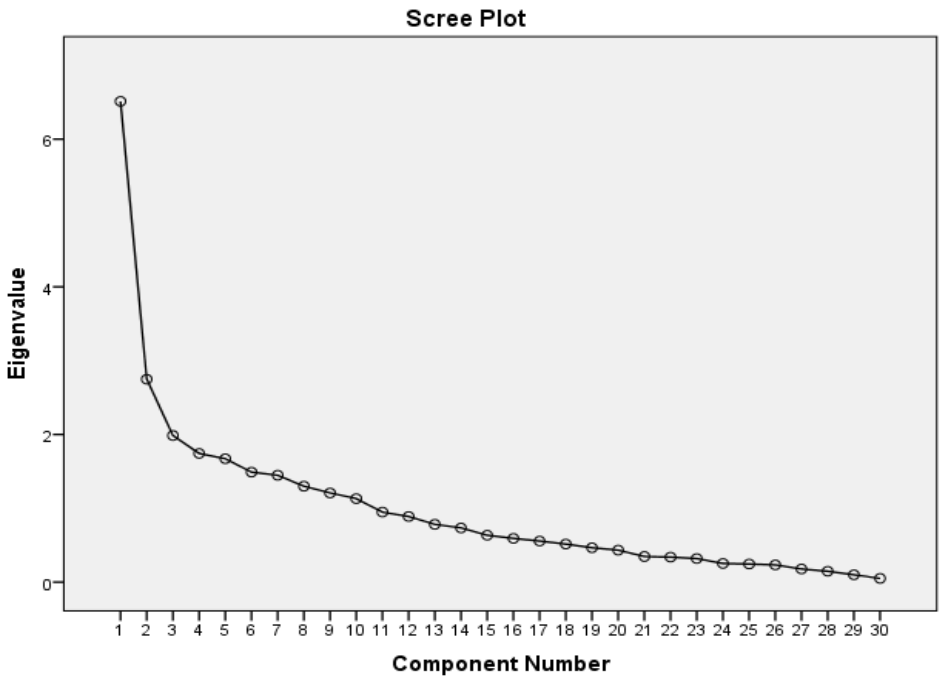

Fig. 1. Scree plot 


\section{Table 2}

The summary of total variance

\begin{tabular}{|c|c|c|c|c|c|c|c|c|c|}
\hline \multirow[b]{2}{*}{ Component } & \multicolumn{3}{|c|}{ Initial Eigen values } & \multicolumn{3}{|c|}{ Extraction Sums of Squared Loadings } & \multicolumn{3}{|c|}{ Rotation Sums of Squared Loadings } \\
\hline & Total & $\begin{array}{c}\% \text { of } \\
\text { Variance }\end{array}$ & $\begin{array}{c}\text { Cumulative } \\
\%\end{array}$ & Total & $\begin{array}{c}\% \text { of } \\
\text { Variance }\end{array}$ & $\begin{array}{c}\text { Cumulative } \\
\%\end{array}$ & Total & $\begin{array}{c}\% \text { of } \\
\text { Variance }\end{array}$ & $\begin{array}{c}\text { Cumulative } \\
\%\end{array}$ \\
\hline 1 & 6.512 & 21.707 & 21.707 & 6.512 & 21.707 & 21.707 & 3.101 & 10.337 & 10.337 \\
\hline 2 & 2.749 & 9.163 & 30.87 & 2.749 & 9.163 & 30.87 & 2.474 & 8.247 & 18.584 \\
\hline 3 & 1.986 & 6.621 & 37.491 & 1.986 & 6.621 & 37.491 & 2.339 & 7.797 & 26.381 \\
\hline 4 & 1.743 & 5.811 & 43.301 & 1.743 & 5.811 & 43.301 & 2.153 & 7.177 & 33.558 \\
\hline 5 & 1.672 & 5.573 & 48.874 & 1.672 & 5.573 & 48.874 & 2.079 & 6.93 & 40.488 \\
\hline 6 & 1.49 & 4.967 & 53.841 & 1.49 & 4.967 & 53.841 & 2.069 & 6.898 & 47.386 \\
\hline 7 & 1.448 & 4.827 & 58.668 & 1.448 & 4.827 & 58.668 & 1.982 & 6.607 & 53.994 \\
\hline 8 & 1.299 & 4.331 & 62.999 & 1.299 & 4.331 & 62.999 & 1.856 & 6.187 & 60.18 \\
\hline 9 & 1.208 & 4.026 & 67.025 & 1.208 & 4.026 & 67.025 & 1.695 & 5.651 & 65.831 \\
\hline 10 & 1.131 & 3.771 & 70.796 & 1.131 & 3.771 & 70.796 & 1.49 & 4.965 & 70.796 \\
\hline 11 & 0.948 & 3.16 & 73.956 & & & & & & \\
\hline 12 & 0.889 & 2.962 & 76.918 & & & & & & \\
\hline 13 & 0.782 & 2.607 & 79.525 & & & & & & \\
\hline 14 & 0.734 & 2.447 & 81.972 & & & & & & \\
\hline 15 & 0.635 & 2.116 & 84.088 & & & & & & \\
\hline 16 & 0.592 & 1.974 & 86.063 & & & & & & \\
\hline 17 & 0.556 & 1.852 & 87.915 & & & & & & \\
\hline 18 & 0.516 & 1.719 & 89.634 & & & & & & \\
\hline 19 & 0.466 & 1.552 & 91.187 & & & & & & \\
\hline 20 & 0.433 & 1.443 & 92.63 & & & & & & \\
\hline 21 & 0.347 & 1.157 & 93.787 & & & & & & \\
\hline 22 & 0.338 & 1.127 & 94.914 & & & & & & \\
\hline 23 & 0.32 & 1.065 & 95.979 & & & & & & \\
\hline 24 & 0.252 & 0.842 & 96.82 & & & & & & \\
\hline 25 & 0.245 & 0.817 & 97.638 & & & & & & \\
\hline 26 & 0.233 & 0.777 & 98.415 & & & & & & \\
\hline 27 & 0.178 & 0.592 & 99.007 & & & & & & \\
\hline 28 & 0.148 & 0.492 & 99.499 & & & & & & \\
\hline 29 & 0.1 & 0.333 & 99.832 & & & & & & \\
\hline 30 & 0.05 & 0.168 & 100 & & & & & & \\
\hline
\end{tabular}

According to the results of Table 2 and Fig.1, it appears that there were five main factors, which could be extracted. Table 3 shows details of PCA analysis after rotation takes place.

Table 3

The results of PCA after rotation

\begin{tabular}{|c|c|c|c|c|c|c|c|c|c|c|c|}
\hline & \multirow{2}{*}{ Factor } & \multicolumn{10}{|c|}{ Rotated Component Matrix ${ }^{\mathrm{a}}$} \\
\hline & & 1 & 2 & 3 & 4 & 5 & 6 & 7 & 8 & 9 & 10 \\
\hline q27 & Segmentation of the market & 0.821 & & & & & & & & & \\
\hline q22 & Distribution channels & 0.664 & & & & & & & & & \\
\hline q19 & Brand equity & 0.597 & & & & & 0.344 & & & & \\
\hline q23 & The competitive structure of the market & 0.589 & & & & 0.362 & & & & & \\
\hline q34 & Incentive policies & 0.415 & & & & & & & & & 0.397 \\
\hline q15 & Customer service & & 0.83 & & & & & & & & \\
\hline q14 & Sellers behavior & & 0.782 & & & & & & & & \\
\hline q11 & NPD & & 0.633 & & & & & & & & \\
\hline $\mathrm{q} 6$ & Label information & & 0.466 & & 0.375 & & & & & & \\
\hline q13 & To compare prices & & & 0.934 & & & & & & & \\
\hline q12 & Cash Discounts & & & 0.905 & & & & & & & \\
\hline q26 & Advertising strategies & & & 0.412 & & & & & & 0.402 & \\
\hline q5 & Marketing channels & & & & 0.908 & & & & & & \\
\hline $\mathrm{q} 4$ & Internet Retail & & & & 0.854 & & & & & & \\
\hline $\mathrm{q} 8$ & Competitive retail & & & & & 0.815 & & & & & \\
\hline q9 & Power Retail & & & & & 0.795 & & & & & \\
\hline q18 & Market share & 0.387 & & & & 0.513 & & & & & \\
\hline q21 & Credit Retail Brand & & & & & & 0.749 & & & & \\
\hline q20 & Brand management & & & & & & 0.698 & & & & \\
\hline q24 & Loyalty Store & & & & & & & 0.762 & & & \\
\hline q29 & Customer loyalty to the brand & & & & & & 0.369 & 0.596 & & & \\
\hline q16 & Shopping Experience & & & & & & & 0.529 & 0.508 & & \\
\hline q33 & Access to the shops & & & & & & & & 0.782 & & \\
\hline q31 & Bargaining power of customers & 0.339 & & & & & & & 0.576 & & \\
\hline q30 & Music & & & & & & & & & 0.713 & \\
\hline q32 & Demand forecast & & & & & & & & & 0.624 & \\
\hline q28 & Supply Chain Management & 0.473 & & & & & & & & 0.492 & \\
\hline q17 & Store household needs & & & & & & & & & & 0.649 \\
\hline q25 & Pricing strategy & & & & & & & & & & -0.598 \\
\hline $\mathrm{q} 2$ & Strategic integration & 0.346 & & & & & -0.399 & & & & 0.426 \\
\hline
\end{tabular}


Based on the results of principal component analysis, the study has detected five factors influencing on organizational competitiveness including effective brand, distribution management, customer strategy, retail location and competitive tools.

\section{Conclusion and discussion}

In this paper, we have presented an empirical investigation to study the effects of different factors influencing a good brand in retail brand. The proposed study of this paper has designed a questionnaire, distributes it among some managers who were enrolled in retail industry in city of Tehran, Iran. Using principal component analysis, the study has detected five factors influencing on organizational competitiveness including effective brand (EB), distribution management (DM), customer strategy (OCS), retail location (RS) and competitive tools (CT). Fig. 2 demonstrates the results of path analysis for investigating the effects of these factors.

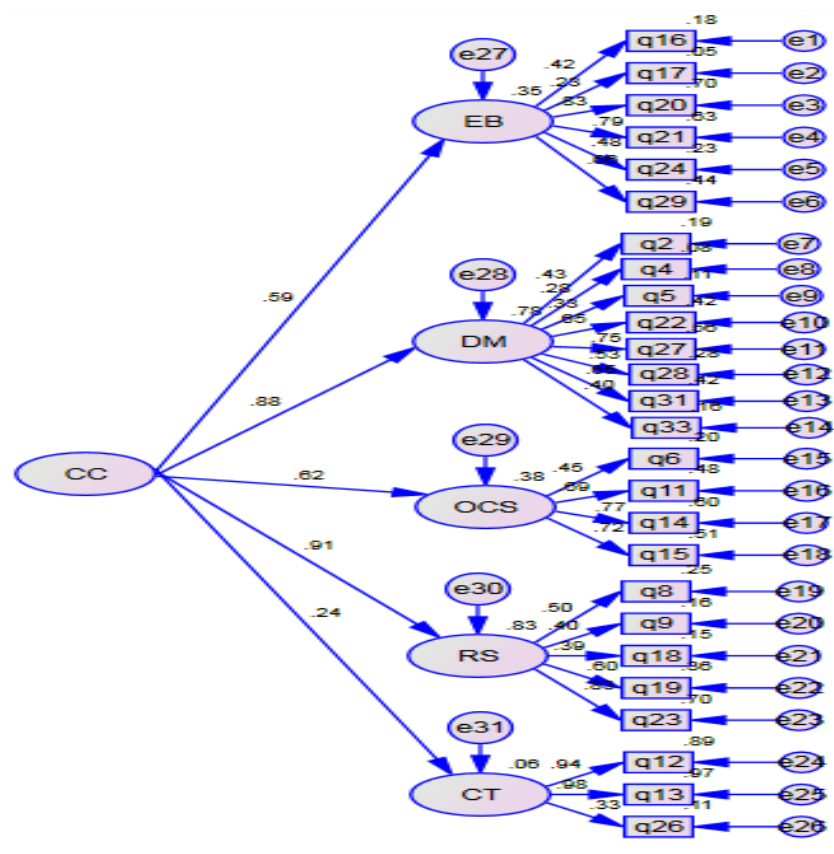

Fig. 2. The results of path analysis

According to the results of Fig. 2, all five components preserve meaningful t-student values. The highest value belongs to retail location $(\beta=1.196)$ followed by distribution management $(\beta=0.825)$, effective brand $(\beta=0.47)$ and competitive tools $(\beta=0.470)$. Note that this study has been accomplished in city of Tehran, which is the capital city of Iran. The city is the host of millions of residences and congestion has increased the number of retail stores in this city. Therefore, retail location plays essential role for development of a successful business in this city and the results of our survey are what we expected in early stage. Distribution management is another important issue in this city. In fact, when a customer does not find what he/she wants from a particular store, he/she may switch to another retail store. The results of this study are consistent with other findings in the literature (e.g. Binninger, 2008; Gee et al., 2008; Guenzi et al., 2009).

\section{Acknowledgement}

The authors would like to thank the anonymous referees for constructive comments on earlier version of this paper. 


\section{References}

Binninger, A. S. (2008). Exploring the relationships between retail brands and consumer store loyalty. International Journal of Retail \& Distribution Management, 36(2), 94-110.

Borghini, S., Diamond, N., Kozinets, R. V., McGrath, M. A., Muniz, A. M., \& Sherry, J. F. (2009). Why are themed brandstores so powerful? Retail brand ideology at American Girl Place. Journal of Retailing, 85(3), 363-375.

Gee, R., Coates, G., \& Nicholson, M. (2008). Understanding and profitably managing customer loyalty. Marketing Intelligence \& Planning, 26(4), 359-374.

Guenzi, P., Johnson, M. D., \& Castaldo, S. (2009). A comprehensive model of customer trust in two retail stores. Journal of Service Management, 20(3), 290-316.

Granot, E., Greene, H., \& Brashear, T. G. (2010). Female consumers: Decision-making in brand-driven retail. Journal of Business Research, 63(8), 801-808.

Keeling, K., Keeling, D., \& McGoldrick, P. (2013). Retail relationships in a digital age. Journal of Business Research, 66(7), 847-855.

Kim, S. H., \& Choi, S. C. (2007). The role of warehouse club membership fee in retail competition. Journal of Retailing, 83(2), 171-181.

Lymperopoulos, C., Chaniotakis, I. E., \& Rigopoulou, I. D. (2010). Acceptance of detergent-retail brands: the role of consumer confidence and trust. International Journal of Retail \& Distribution Management, 38(9), 719-736.

Pan, Y., \& Zinkhan, G. M. (2006). Determinants of retail patronage: a meta-analytical perspective. Journal of Retailing, 82(3), 229-243. 